\title{
SOVIET HUMAN RIGHTS: LAW AND POLITICS IN PERSPECTIVE
}

\author{
EUGENE D. FRYER*
}

The contemporary disposition toward the socialist approach to human rights, focused principally upon Soviet practice in the context of the 1975 Helsinki Final Act, ${ }^{1}$ at the present seems to be without well-articulated meansend relationships and objectives.

This is not to say that the present critique is deficient in expectations. The 1948 Universal Declaration of Human Rights has explicitly established the aspirational humanitarian objectives of this epoch. ${ }^{2}$ Neither does the critique of socialist practice lack its grievances. These are principally centered on socialist, cum Soviet, practice contrary to the human rights undertakings fashioned in this generation to give effect to the 1948 Declaration. ${ }^{3}$ These international standards, unlike the 1948 Declaration, are not merely aspirational, but are as legally binding as any international treaty can be. ${ }^{4}$ The enumeration of specific shortfalls from these standards, or of pointed violation of their clear requirements, are well catalogued. ${ }^{5}$ The elimination of these disparities

* Major, Judge Advocate General's Corps, United States Army; Chief, International Law Division, The Judge Advocate General's School, Charlottesville, Va. The author's views do not purport to reflect those of the U.S. Army or Defense Dept.

1. Final Act, Conference on Security and Cooperation in Europe, done at Helsinki, August 1 , 1975, U.S. Def't of State, Pub. No. 8826, General Foreign Policy Series 298 [hereinafter cited as Final Act]; 14 Int'l Legal Materials 1292 [hereinafter cited as ILM].

2. International Bill of Human Rights: A Universal Declaration of Human Rights, G.A. Res. 217, U.N. Doc. A/810, at 71 (1948).

3. International Convention on the Elimination of All Forms of Racial Discrimination, G.A. Res. 2106, 20 U.N. GAOR Supp. (No. 14) 47, U.N. Doc. A/6014 (1965); International Covenant on Civil and Political Rights, G.A. Res. 2200, 21 U.N. GAOR Supp. (No. 16) 52, U.N. Doc. A/6316 (1966); International Covenant on Economic, Social and Cultural Rights, G.A. Res. 2200, 21 U.N. GAOR Supp. (No. 16) 49, U.N. Doc. A/6316 (1966); the Soviet Union has ratified the above three instruments; Final Act, Conference on Security and Cooperation in Europe, supra note 1 .

4. The Helsinki Final Act is a political undertaking and not a binding arrangement under in ternational law. An unavoidably obligatory tone is imparted; however, to the human rights un. dertakings of the Final Act by Principle VII, "[r]espect for human rights and fundamental freedoms, including the freedom of thought, conscience, religion or belief:"

In the field of human rights and fundamental freedoms, the participating States will act in conformity with the purposes and principles of the Charter of the United Nations and with the Universal Declaration of Human Rights. They will also fulfil their obligations as set forth in the international declarations and agreements in this field, including inter alia the International Covenants on Human Rights, by which they may be bound.

5. Basket Three-Implementation of the Helsinki Accords: Hearings on the Implementation of the Helsinki Accords Before the Commission on Security and Cooperation in Europe, 95th Cong., 1st Sess., Vols. I-III (1977) [hereinafter cited as Hearings]; A Chronicle of Current Events: Journal of the Human Rights Movement in the USSR, Vol. I (Amnesty International trans. 1968); AM- 
and the pursuit of the general humanitarian objectives of the 1948 Declaration, as expanded by subsequent covenants, would seem to establish a necessary means-end program for the present critique. This is not the case.

Instead, this means-end program, difficult to pursue in its own right, has been complicated, even frustrated, by its entanglement with considerations from which it should best be kept separate. The objective of expanded human rights under socialism is ill-served, for instance, by its assimilation directly to other nations' foreign policy concerns with counter-militarism, specifically arms limitation and force reduction, or with the containment of Soviet imperialistic tendencies. Finally, there is little prospect for betterment of human rights within socialist authoritarian states if that betterment is linked to a demand that the authoritarian or socialist nature of such states be substantially modified. ${ }^{6}$

These issues are collateral to an incremental enhancement of human rights under socialism. Indeed, the expansion of human rights need not be related directly to the attenuation of militarism, imperialism and authoritarianism, for these phenomena possess their own dynamic and, with time, will experience self-attenuation as the result of both regular and internal socio-economic pressures $^{7}$ and of the measured application of foreign policy instruments at the state-to-state level. The human rights factor certainly may be externally aggravated for foreign policy purposes to refocus Soviet attentions somewhat to domestic conditions, but this is not indispensable to the greater foreign policy objectives of counter-militarism and counter-expansionism. External exploitation of domestic Soviet human rights expectations quite likely has a negative effect upon latent liberalizing tendencies, since conservative reaction has been and will be the predictable system response.

The enhancement of human rights in the Soviet system can and should proceed as the result of ordinary, not induced processes, providing that the authoritarian socialist state is a fairly permanent establishment and acknowledging that a human rights change for the better will be slow, perhaps glacially so. This presupposes, too, that the end result will be a compromise synthesis of some adequate level of individual protection with statist socialism, a product somewhat short of Western ideals, but realistic in view of international and domestic Soviet power factors, and perhaps of Russian cultural considerations.

Consider, for example, the course of Soviet human rights since the death of Stalin in 1953. There followed a reassessment by the Party of the proper

nesty International, Prisoners of Conscience in the U.S.S.R.: Their Treatment and ConDITIONS (1975).

6. In contrast, displacement of the Communist Party is seen by Andrei Amalrik as the only path to viability for Soviet society. Such displacement, in Amalrik's view, will likely be attended by marked upheaval and violence. See, A. Amalrik, Will the Soviet Union Survive Until 1984? 40 (1970) [hereinafter cited as AMALRIK].

7. J. Kautsky, The Political Consequences of Modernization 195-96 (1972). 
balance between state authoritarianism and the right of society to live free of terror ${ }^{8}$ In 1956, following Khruschev's "secret speech" denouncing the Stalin excesses, ${ }^{9}$ a period of relaxation ensued, publicly proclaimed as a return to the principles of socialist legality originally laid out in Stalin's own mooted 1936 constitution. ${ }^{10}$ To be sure, the control of the Party clearly was maintained, even enhanced; for above all, the Party was to be placed beyond the terror and manipulation that had deprived it of any operational efficacy since at least the mid-1930s. Additionally, Soviet society was to pursue the construction of socialism with a cultivated but voluntary discipline, felt by individuals and translated into positive collective action.

But there followed during this period an internal relaxation of the Soviet style of governance which had not been experienced since Lenin's New Economic Policy (NEP). ${ }^{11}$ This perhaps was a period of searching for new parameters in the relationship of the individual to the socialist state and for the post-Stalin threshold of the Soviet state's authoritarian preserve. During this time and for as long as perhaps five years, the Party, under Khruschev, permitted a controlled and limited resurgence of perceptive literature and art, said by some to be the self-serving move of Khruschev personally and of the Party in general to enhance its popular support by a public expurgation of Stalinistic excesses. ${ }^{12}$

Whatever the motive, at the height of the Cold War, Soviet society relaxed at the popular level, concurrently with the maintenance of high-level Warsaw Pact-NATO confrontation, with the resubjugation of Hungary, with the tightening of authoritarianism throughout eastern Europe, with the construction of the Berlin Wall, and the Cuban missile episode.

When the threshold of social relaxation had been approached by $1962,{ }^{13}$

8. L. Schapiro, The Communist Party of the Soviet Union 573-74 (2nd ed. 1970) [hereinafter cited as Schapiro]; Z. Brzezinski, The Soviet Bloc: Unity and Conflict 113, 180 (1967).

9. See, Khruschev's secret speech to the Twentieth Congress of the Communist Party of the Soviet Union, 1956, reprinted in The Anti-Stalin Campaign and International Communism 2 (Russian Institute of Columbia University ed. 1956).

10. Konstitutsia (Constitution) (USSR 1936, amended Nov. 7, 1967) reprinted in J. HAZARD, The Soviet System of Government app., at 219 (4th ed. 1968) [hereinafter cited as Hazard].

11. The New Economic Policy (NEP), initiated by the Tenth Party Congress in March 1921, signalled Lenin's move away from austere "war communism" toward a less collectivist form whereunder a measure of individual initiative was tolerated, along with a limited restoration of capitalist economy, again without jeopardy to the Party's leading role. The NEP, in fact, was pointed at strengthening the position of the Party at its lowest ebb in popularity following the 1917-1920 civil war and the March 1921 Kronstadt Rebellion. By 1927, the NEP was completely dismantled by Stalin in anticipation of his first Five Year Plan and its forced collectivization, industrialism and reinstitution of rigid state discipline. B. DMYTRYSHYN, USSR: A CoNCISE HiSTORY 113-21, 143 (2d ed. 1971). The legal aspects of NEP are discussed in HAZARD, supra note 10, at 149-51.

12. Z. Brzezinski \& S. Huntington, Political Power: USA/USSR 247 (1964). It was during this period that Alexander Solzhenitsyn was officially permitted to publish his historical literary work, One Day in the Life of Ivan Denisovich, an account of life in the Stalin labor camps.

13. Khruschev's display of pique over artistic liberalism at a December 1, 1962 art exhibit at 
there was little sign that a regression to the Stalinist style was the desired or necessary approach to the reapplication of social discipline. Indeed, following Khruschev's ouster on October 14, 1964, there seemed little substantial cause for a conservative relapse in the sphere of individual-authority relations. On the contrary, the major manifestations of Khruschev's unorthodoxy that required conservative compensation lay not in individual-authority relations, but in his experimentation with the relation of the Party to the economy and in foreign policy adventurism.

These major errors were set straight shortly by Khruschev's successors, ${ }^{14}$ but a conservative overcompensation in the reapplication of state authority in the social sphere followed as well. To characterize this shift as overcompensation seems accurate, since at this time there appeared to be no substantial popular effort to exploit the post-Stalin breathing space for broader political reform. The programmatic reapplication of state authoritarianism in matters of public discourse, in literature and in the arts was probably a spillover from the reassertion of power within top party circles by those holding conservative values generally. Thus, those who were inclined against unorthodoxy in Partyeconomy relations and in foreign policy were by their nature also disinclined toward social liberalism. The revival of conservatives at the top of the power structure signaled a return across the board to bureaucratic conservatism. ${ }^{15}$

A great deal may be made of "liberal-conservative" factionalism which then and now exists at the top of the Party and of the effect of this dynamic upon variations in individual-authority relations. It is proposed here that in the view of the incumbent conservative leadership, such variations are a byproduct of other concerns, rather than the result of conscious manipulations, as they were under Khruschev. That human rights are not now permitted to float to their optimal level, as may have been the trend during the Khruschev de-Stalinization period, is the function of two factors.

First, assuming that it was not a self-serving manipulation by Khruschev, post-Stalin liberalization occurred during a period of fairly high Soviet national solidarity and in fact served to enhance that solidarity. Second, and correlatively, there existed at Stalin's death little "other-mindedness" in a Soviet population cowed by the Stalin terror. ${ }^{16}$ The social liberalization that followed until at least 1963 was a fairly well controlled social process, guided by the Party with society following at a measured pace. Concurrently with the institu-

the Manege in Moscow is thought to represent the end of the post-Stalin relaxation. Fainsod, The Role of Intellectuals in the Soviet Union, in Man, State, and Society in the Soviet Union 478 (J. Nogee ed. 1972).

14. SCHAPIRO, supra note 8 , at 572-80.

15. See R. Medvedev, On Socialist Democracy 48-49 (E. de Kadt trans. and ed. 1975) [hereinafter cited as Medvedev], analyzing the Party's return to conservatism, a movement that Medvedev does not indorse.

16. F. Feldorugge, Samizdat and Political Dissent in the Soviet Union 4 (1975) [hereinafter cited as Feldorugge]. 
tion of Brezhnev's conservative regression, this other-mindedness began to develop more fully, perhaps partly in reaction to the creeping restrictiveness in social democracy in the early 1960s. The samizdat and other forms of extralegal articulation, which had been largely crushed under Stalin and then rendered superfluous during Khruschev's reforms, now crept back onto the scene. ${ }^{17}$ As the conservative leadership tightened the ratchet on social liberalization, individual divergences from the new norms inevitably cropped up more frequently. By 1965 this scattered disillusionment had assumed the tone of dissent-although on a measured and isolated scale-and of growing defiance of existing legal norms. ${ }^{18}$

17. The Soviet Censorship (M. Dewhirst \& R. Farrell eds. 1973) [hereinafter cited as Dewhirst \& Farrell], passim. On samizdat, see note 20 infra.

18. Article 125 of the 1936 Stalin Constitution provided for explicit constraints on the rights of Soviet citizens to free speech, press and assembly:

In conformity with the interests of the working people, and in order to strengthen the sócialist system, the citizens of the U.S.S.R. are guaranteed by law: [the rights to speech, press and assembiy are then enumerated].

Konstitutsia (Constitution) art. 128 (USSR 1936), reprinted in HAZARD, supra note 10, at 239. The newly adopted 1977 "Brezhnev" Constitution provides no real change from the 1936 Constitution: "In accordance with the [working] people's interests and for the purpose of strengthening and developing the socialist system, USSR citizens are guaranteed freedom of speech, of the press, of assembly. .." The Current Digest of the Soviet Press, Nov. 9, 1977, at 6. ("Working" appeared in a draft of the Constitution, but was deleted in the final version. "And developing" did not appear in the draft version, but was added to the final version.)

Criminal law sanctions for violation of this constitutional constraint are provided by Article 70 of the Criminal Code of the RSFSR and analogous provisions of the criminal codes of the other Union Republics:

Anti-Soviet Agitation and Propaganda. Agitation or propaganda carried on for the purpose of subverting or weakening the Soviet regime [vlast'] or of committing particular, especially dangerous crimes against the state, or the circulation, for the same purpose of slanderous fabrications which defame the Soviet state and social system. or the circulation or preparation or keeping, for the same purpose, of literature of such content, shall be punished by deprivation of freedom for a term of six months to seven years, with or without additional exile for a term of two to five years.

The same actions committed by a person convicted of especially dangerous crimes against the state or committed in wartime shall be punished by deprivation of freedom for a term of three to ten years, with or without additional exile for a term of two to five years. [ $V e d$. (1962), No. 29, item 449, Edict July 25, 1962] reprinted in H. Berman \& J. Spindler, Soviet Criminal Law and Procedure. Conduct in violation of Article 70 constitutes an "especially dangerous" crime against the state.

In 1966, in response to the particular problems of proof of slanderous purpose posed by Article 70 in the Sinyanski-Daniel trial (they pleaded lack of requisite intent), article 190-1 was added to the criminal code. Under this enactment the defamatory character of the utterance is a question not of intent but of fact. Article 190-1 is now applied to the majority of speech-related dissident offenses.

Article 190-1. Circulation of Fabrications Known to Be False Which Defame Soviet State and Social System. The systematic circulation in an oral form of fabrications known to be false which defame the Soviet state and social system and, likewise, the preparation or circulation in written, printed or any other form of works of such content shall be punished by deprivation of freedom for a term not exceeding three years, or by correctional tasks for a term not exceeding one year, or by a fine not exceeding 100 rubles. [ $\mathrm{Ved}$. (1966), no. 38, item 1038, Edict September 16, 1966.] Id. at 180-81. 
The 1965 trial for anti-Soviet slander of Sinyanski and Daniel ${ }^{19}$ registered the regime's concern that despite social retrenchment, the permissible boundary of social liberalization had been exceeded. The samizdat impulse intensified in reaction to this particular repression and to the subsequent tightening of police controls over intellectual dissent. Under the conservative regime, other-mindedness assumed a boldness which was unknown during the most liberal period of Khruschev's social experimentation. ${ }^{20}$ A spectrum of divergence coalesced around the samizdat media, ranging from fundamental national chauvinism to religious revivalism, to neo-Leninist reform, to rule-oflaw democratic socialism. ${ }^{21}$ The Czechoslovakian pacification by the Soviet-led Warsaw Pact further galvanized the democratic elements of this dissent into something approximating an incipient movement, despite increasing repression. ${ }^{22}$ While this democratic opposition was largely suppressed in the early to mid-1970s, ${ }^{23}$ it provided the inspirational nucleus, despite the attrition and

19. ON Trial: The Soviet State Versus "Abram Terz" and "Nikolai Arzhak" (Max Hayward, trans. and ed. 1966).

20. On Soviet censorship and the government's monopoly over ideas, see generally Dewhirst \& Farrell, supra note 17. For a short but detailed description of the operation of Glavlit, the Soviet censorship mechanism, see Vladimirov, Glavit: How the Soviet Censor Works, Index on Censorship, Aut./Win. 1972, at 31 .

All official publication in the Soviet Union is accomplished through state-owned publishing houses following governmental and semi-official vetting described in the above sources. All equipment associated with the production of literature for public readership is state-owned, whether it be heavy presses or manually operated mimeographs. During Stalin's time, typewriters were also controlled items, being subject to state registration, but this is no longer the case. See Loeber, Samizdat Under Soviet Law, INDEx on Censorship, Aut./Win. 1973 at 16.

Publication outside this official regimen is possible, employing the scant means available to the individual, usually through cooperative, hand-to-hand typewriter reproduction. This selfpublication, or samizdat, is not illegal per se, although it stands outside approved Soviet procedure. Samizdat's illegality, rather, lies in its content, which may range in time and according to official sensibilities from innocuous to criminally actionable. See note 18 supra. For the legal status of samizdat, see Loeber, Samizdat Under Soviet Law, Index on CrNSOrSHIP, Aut. 1973, at 3.

A sound official view on this wavy, ad hoc boundary between safe and objectionable public utterance is provided in Chkhikvadze, The State, Democracy and Legality in the U.S.S.R.: Lenin's Ideas Today 208, 218-24 (D. Ogden trans. 1972). The same demarcation is viewed by one who often challenged its authority in Chalidze, To Defend These Rights (G. Daniels trans. 1974) [hereinafter cited as CHALIDzE].

Samizdat just as accurately may include self-published material of whatever type which does not make its first appearance within the Soviet Union, but which is smuggled abroad for wider publication, perhaps to be reintroduced later into the Soviet Union in printed samizdat form. Such reentry may be accomplished by radio broadcast from numerous Western radio stations. This form of material, radizdat, is said to combine with other forms of self-publication to afford some measure of cross-pollenization of oppositional thinking. FELdBrugGe, supra note 16, at 6 .

21. Feld Bugge, supra note 16 at 104 .

22. For the operative facts and Soviet legal theory attending the invasion of Czechoslovakia, see Ramundo, Czechoslovakia and the Law of Peaceful Coexistence: Legal Characterization in the Soviet National Interest, 22 STANFord LAW REv. 963 (1970). Outrage over the force of Soviet will upon the Czech liberalizers was a singular galvanizing force for the democratic opposition during the 1960s. Feldbrugge, supra note 16, at 109, 111. See also, Chalidze, supra note 20; M. Hayward, supra note 19.

23. Hearings, supra note 5, at 24. See also, id. at 25-39. 
turnover of personalities, for today's democratic opposition, which operates in various parts of the Soviet Union under the rubric of the Helsinki Agreement's human rights monitoring groups. ${ }^{24}$

These groups and individual dissidents are dealt with by increasingly Draconian means. The application of legal controls, ${ }^{25}$ administrative sanctions ${ }^{26}$ and psychiatric measures ${ }^{27}$ has reached a high point indeed when measured against either the Khruschev period or Lenin's NEP. Official repression of dissent now more nearly approximates the conditions of the Stalin era, without indiscriminate mass terror. In terms of the facility of the legal system as a tool for securing social discipline, in terms of the resort to extra-legal repression, ${ }^{28}$ In terms of the polemics in the Soviet press against social permissiveness, ${ }^{29}$ the climate in the Soviet Union for an expanded application of human rights is at least adverse and worsening.

Given this hyper-reactive and retrogressive approach by the Soviet leadership to social liberalization, how can any real enhancement in the condition of Soviet human rights be pursued through highly visible international demarche, likely on the one hand to stir Soviet defensiveness and on the other to heighten the expectations of the Soviet opposition. Either of these reactions to conspicuous external aggravation of the already destabilized Soviet human rights situation will only further intensify reactionary forces. The only result of such aggravation can be the further validation of the Stalinist style in the hands of the conservatives, who will likely be facilitated thereby in their effort to remain in power after Brezhnev.

At the same time, a broadening of public antiregime sentiment is conceivable, perhaps in concert with similar popular movements in authoritarian Eastern European regimes. This breakdown of social control may begin as a spreading of expectations from the intellectual opposition to national, religious, economic and perhaps aspirational (class-oriented) elements. The result

24. "Open Letter to Representatives of States Participating in the Belgrade Conference" (September 1977). Khronika Press, 505 Eighth Avenue, New York, New York 10018.

25. Chalidze, supra note 20 , at 67-68.

26. See note 5, supra.

27. S. Bloch \& P. Reddaway, Psychiatric Terror: How Soviet Psychiatry Is Used to Suppress Dissent (1977); see also, Fainberg, My Five Years in Mental Hospitals, Index on CensorSHIP, Summer 1975, at 67.

28. In recent years, with the landmark being the forcible exile in February, 1974 of Solzhenitsyn, the Soviets have increasingly resorted to external exile as a device for reducing the domestic influence of dissidents. External exile was abolished de jure as part of the 1958 Soviet criminal law reform. I. Lapenna, Soviet Penal Policy 88 (1968).

29. See, e.g., The Bukovsky Case and Soviet Law, Literaturnaya Gazeta, Oct. 27, 1976, at 9, reprinted in Current Digest of the Soviet Press, Dec. 1, 1976, at 1; Pravda Hits West's Defense of Dissidents, Pravda, Feb. 12, 1977, at 4, reprinted in Current Digest of the Soviet Press, March 10, 1977, at 1; Gusev, Moscow, on Sakharov, New York Trmes, Feb. 23, 1977, at A-23, col. 3; Letter from Aleksandr Petrov to Literaturnaya Gazeta, Feb. 2, 1977, at 14, reprinted in CuRRent Digest of the Soviet Press, Feb. 23, 1977, at 3. 
of such a scenario is not fanciful: perhaps a revival of neo-Stalinism to preserve the status quo, or the failure of such a regime attempt and the disintegration of a complex social system into contending national, ethnic and interest sectors, not the least of which would be conservatively oriented communist traditionalists and patriotic Russian nationalists. This formula guarantees little but bloodshed and the widespread, probably protracted diminution of human values in a balkanized Soviet society. ${ }^{30}$ The worst case projection of this development should include the Soviet application internationally, perhaps without justifiable cause, of nuclear force to hold back those foreign powers who might exploit domestic upheaval to alter international power relationships. ${ }^{31}$

In either its neo-Stalinist or disintegrative aspect, this destabilizing approach, this exacerbation of the defensive syndrome and of unjustifiably aroused expectations can do little to further the cause of world order and the maximization of human values. On the contrary, the means-end program for an expansion of human rights under socialism lies in the evolutionary, not the disintegrative potential of the conservative Soviet system. In most cases the pace of this process necessarily will be less than that which would suggest a measurable cause-effect response to the foreign policy process.

The key to this slow liberalization lies in the Soviet leadership's slow advance from reactive bureaucratic conservatism to the rational style of management, and therefore of governance, required of a modernizing social system. The Soviet Union has run its course of basic nation-building, with authoritarianism providing the motive force for crash industrialization and economic collectivization. ${ }^{32}$ Victory was procured from a cataclysmic world war and economic reconstruction from a wasted national territory. The question today, however, is whether the old authoritarian style is appropriate under condi-

30. This is Amalrik's crisis theory. See AMALRIK, supra note 6, at 40.

31. A. Ulam, American-Soviet-Chinese Relations: Some Reflections; The Great Power Triangle; Selected Comments, Subcommittee on National Security and International Operations of the Senate Committee on Government Operations, 92d Cong., 1st Sess. 31 (1971). [This material is reprinted from A. Ulam, The Rivals: America and Russia Since World War II (1971)].

The dangers of the nuclear age then impose a peculiar consideration of prudence and conservatism upon both superpowers [the U.S.S.R. and the United States-EDF]. Neither can afford a violent internal conflict nor wish such troubles upon the other. This is a somber reflection, for it prevents us from wishing that for their own sake as well as that of the world the Soviet people could drastically alter the system under which they live. Requirements of peace, more particularly of saving the world from a nuclear holocaust which a tottering totalitarian regime might unleash, take precedence over those of democracy. We should not expect that the regime we will deal with in Russia for many years to come will be other than an authoritarian one, that any basis for accommodation with the U.S.S.R. will be other than one of mutual interest. Id. at 31 .

32. These same ends may well have been attainable through less drastic means. The economic and human casualty attributable to the early Bolshevik and later Stalin excesses may well have been channeled to the very tasks from which they were diverted. I. Deutscher, Stalin: A Political Blography 311-57, 624 (2d ed. 1967); Medvedev, supra note 15, at 239; A. Solzhenitsyn, The GulaG ArChipelago 1918-1956 (T. Whitney trans. 1973), at 55-57. 
tions of "developed socialism,"33 increasing well-being and putative domestic stability. ${ }^{34}$

Regressive authoritarianism may well be a stereotyped response by the Soviet regime to the threat seen in the various elements of present day dissent, to the threat perceived from the human rights foreign policy of the nonsocialist world, and to the threat to ideological insulation posed by the penetration into the Soviet Union of alien ideas through foreign literature, radio broadcasts $^{35}$ and foreign contacts. But this is only one aspect of the problem facing the ageing Soviet leadership, a leadership subject to displacement in the near future by groups now quietly contending over the present regressive style of governing and its alternatives.

The challenge to liberalization in the Soviet Union at this point does not involve blatant denials under legal and other formulae of the rights of Soviet citizens to free assembly, speech, press and to security of the person in all of its aspects. The main challenge at present is that the leadership cannot relinquish to the proper sectors the measure of operating discretion necessary to more fully rationalize national output priorities, development, production and distribution. The Party remains locked into rigid national planning and control of managerial supervision down to the lowest operating level, despite the fact that these forms have outlived all utility save ideological consistency and the preservation of vested interests. ${ }^{36}$ There has developed in the Soviet Union a significant, but bridled, non-apparatus leadership capability-in the enterprises, in the professional and technical institutes, and in the bureaucracy itself-which is capable of contributing to rationalized national decisionmaking.

It is from this source that a moderation of the authoritarian style may issue as the Party on the one hand finds its way toward assimilating this group and thereby of transforming itself to a rationalized, less ideological institution. On other hand, the Party may assume a less exclusive role through cooperation with, while still controlling, various harmonious extra-party rationalizing

33. Currently, the Soviet progression from bourgeois overthrow to pure communism is said to be at the point of a "developed socialist society," as described in the Preamble to the 1977 Constitution of the U.S.S.R. The Current Digest of the Soviet Press, Nov. 9, 1977, at 1.

34. Principal observers on all gradations of the oppositional spectrum reject the efficacy of reactionary authoritarianism in a modernizing Soviet society. See generally AmALRIK, supra note 6; A. Sakharov, Progress, Coexistence and Intellectual Freedom (N.Y. Times trans. 1968); MedVedev, supra note 15.

35. See note 20 supra. The sensitivity of the Soviet Union and Eastern European regimes to the activities of Radio Free Europe, Radio Liberty and RIAS has been strongly voiced in sessions of the Belgrade follow-up conference to the 1975 Helsinki Conference. N.Y. Times, Sept. 10, 1977, § A, at 26, col. 1; id., Sept. 30, 1977, § A, at 6, col. 1; id., Jan. 23, 1978, § A, at 9, col. 3; U.S. Dep't of State, Fourth Semiannual Report by the President to the Commission on SeCURITY AND CoOperation IN EuRope, 24 (1978).

36. See J. Hough, The Soviet Prefects: The Local Party Organs in Industrial Decision MAKING, at 178 (1969). 
interests. ${ }^{37}$ In this pressure toward modernization lies the best hope for the ultimate betterment of Soviet human rights; the destability model promises only regressive authoritarianism. Modernizers and rationalizers, as any other group, also may be inclined toward authoritarian repression to preserve their advantage, and may thus become the defenders of a new status quo, armed in addition with an ideology suited to this purpose. But this is neither an inevitable nor a permanent condition. They, too, by necessity may be compelled to moderate, to accept or to coexist with domestic influences hopefully pushing toward an incremental lessening of authoritarianism. In any event, keeping this tendency on a liberal course should be the prime interest of the foreign policy of interacting states, rather than the fueling of retrogressive tendencies by providing dissidents with the basis for demands for sudden and systemic change.

How then to abet a slow but productive movement away from authoritarianism while minimizing present day excesses in the violation of human rights? This dilemma is the essence of today's foreign relations, for Soviet as well as for Western policy. Foreign policy and human rights cannot be viewed as Soviet negatives being manipulated by Western positives. There are reciprocal interests here, as well as antagonisms. On the one hand, the Soviet Union is faced with its somewhat diminished commitment forever to steer clear of Stalinist repression; at the same time, it must allow vent to individualistic and pluralistic tendencies which are the product of a modernizing, educated society, aspiring to a quality of life often at odds with social discipline.$^{38}$

37. The new Soviet constitution has conspicuously enhanced the legal status of the Communist Party of the Soviet Union over its former oblique position as only the leading, most active and politically conscious of all Soviet public organizations. Konstitutsia (Constitution) art. 126 (U.S.S.R. 1936), reprinted in HAZARD, supra note 10, at 239-40. Article 6 of the Constitution of 1977 gives exclusive treatment to the Party's role without reference to other public organizations. Contrasted to the 1936 provision, the new constitution is explicit on the overt political and statal role of the Party:

Article 6. The Communist Party of the Soviet Union is the leading and guiding force of

Soviet society, the nucleus of its political system and of all state and public organizations. The CPSU exists for the people and serves the people.

Armed with the Marxist-Leninist teachings, the Communist Party determines general prospects for the development of society and the lines of the U.S.S.R.'s domestic and foreign policy, directs the great creative ability of the Soviet people, and gives their struggle for victory of communism a planned, scientifically substantiated nature.

KonstituTsia, art. 6 (U.S.S.R. 1977), supra note 33 at 2.

This straightforward constitutional legitimization of the Party at first glance seems to provide sound insulation against erosion and displacement of the Party over time as the discipline of the Stalin period fades and new generations assume leadership. The security of such legal institutionalization may, by the same token, permit the Party to undergo, without suffering legal and fatal mutation, a degree of base-broadening in response to its natural penetration by rationalizing elements.

38. The phenomenon of giving vent to social pressures may just as well lie at the heart of the Khruschev liberalizations as any more ulterior explanation. Similarly, that dissident themes have indeed existed in Soviet society since that time may indicate more than a Soviet inability to sup- 
The better course (aimed at securing a broadened, though undramatic betterment over time in human conditions) is a U.S. foreign policy emphasizing the carrot over the stick. The human rights issue should be separated from the geopolitical concerns over Soviet imperialism and over arms control, and these concerns treated as discrete issues without the employment of human rights as a bargaining chip; the latter tactic can only bode ill for the present day status of human rights and of individual dissidents. The framework has been built for the push of the Soviet Union along the road toward moderation. This framework arises from the network for bilateral relations established in the early detente period between the Soviet Union, the United States and others.

These relations were defined throughout the Helsinki Final Act, chiefly by Principle IX, Cooperation Among States, of Basket I, Declaration on Principles Guiding Relations Between Participating States, ${ }^{39}$ and by the undertakings in the section on Cooperation in the Field of Economics, of Science and Technology and of the Environment. It is in these areas that, through contact and relations over time, the more moderate tendencies in Soviet authority may be strengthened at the expense of the dogmatic and xenophobic. Similarly, the more benign provisions of Basket 3, Cooperation in Humanitarian and Other Fields, are proper grounds for present, direct, but nonantagonistic dealings. ${ }^{40}$ Emphasis here should focus upon those aspects of human contacts and circulation of information and of cultural and educational cooperation that do not raise the immediate specter of the sudden penetration today of permissiveness, or of the diminution of Party control over behavior or ideas.

press these phenomena, but an intention instead to permit a degree of open venting of "othermindedness." Toleration of discordance can serve several useful purposes beyond supporting the claim internationally that Soviet society is in fact an open society. Additionally, the regime obtains a barometer of sorts, indicating how a small but perhaps symptomatic segment of society perceives its milieu generally and present Soviet policy in particular. In a country that otherwise permits little upward percolation of popular critical thought, the dissident phenomenon may represent a useful form of social feedback and perhaps of social input.

Similarly, the Jewish emigration since 1967 and the outflow of ethnic Germans since 1972 can be interpreted as much as an example of sensible social venting as a defensive response to international indignation and diplomatic pressure. Here, after all, are groups which for reasons distinct from international pressure have elected to disassociate with Soviet society. Or perhaps their number represents a failure of the idea of assimilation to a society characterized by increasing hostility and decreasing prospects for mobility and opportunity-changes which may reflect official defensiveness to the international focus drawn to these groups.

39. Principle IX, Basket I, Final Act, supra note 1, at 81: ILM, supra note 1, at 1295.

40. Realistic progress in relations and an ultimate softening in internal Soviet conditions may be had by pursuing the short run humanitarian objectives of Basket 3 without boldly striking today to accomplish the more long range objective of liberalization in areas which imminently threaten the Party's monopoly over social behavior and ideas. The major fields for cooperation detailed in Basket 3, Final Act, supra note 1, at 113, i.e., Human Contacts; Information; Cooperation and Exchanges in the Field of Cultures; Cooperation and Exchanges in the Field of Education, can all be pushed vigorously without the concomitant demand that domestic controls and standards be modified. These controls perforce will undergo natural modification as the maturation of Soviet society and its changing leadership admits. 
This process of relaxation, which may be protracted to the dissatisfaction of many observers and interested parties within and without the Soviet Union will doubtless be accompanied by continued individual or uniform violations of human rights. This behavior justifiably will draw the expressed concern of external supporters of human rights. But the representations and inducements of foreign governments on behalf of better treatment or individual relief are best conducted obliquely; that approach will be most compatible with the ongoing push for the unavoidable self-reorientation of the Soviet leadership's domestic outlook.

A program for the enhancement of human rights under authoritarian Soviet socialism should thus be aimed at the reduction of the conservative authoritarian element. The product of blatant authoritarianism-systematic and mass violation of human rights-has largely passed with Stalin's death. The task of expanded human rights protection, and therefore of a human rights oriented foreign policy, should be to assure that conservative elements have little pretext to revive this repressive condition, and that there is little to detract from a moderation which could develop from within the Soviet Union, given the proper environment. The attenuation of authoritarianism is the end and the means lie in closer, nonantagonistic relations between the Soviet Union and those nations that seek the enhancement of human rights. Thus, ultimate betterment of human rights will be achieved not as a direct result, but as the ultimate byproduct of patient international relations. 